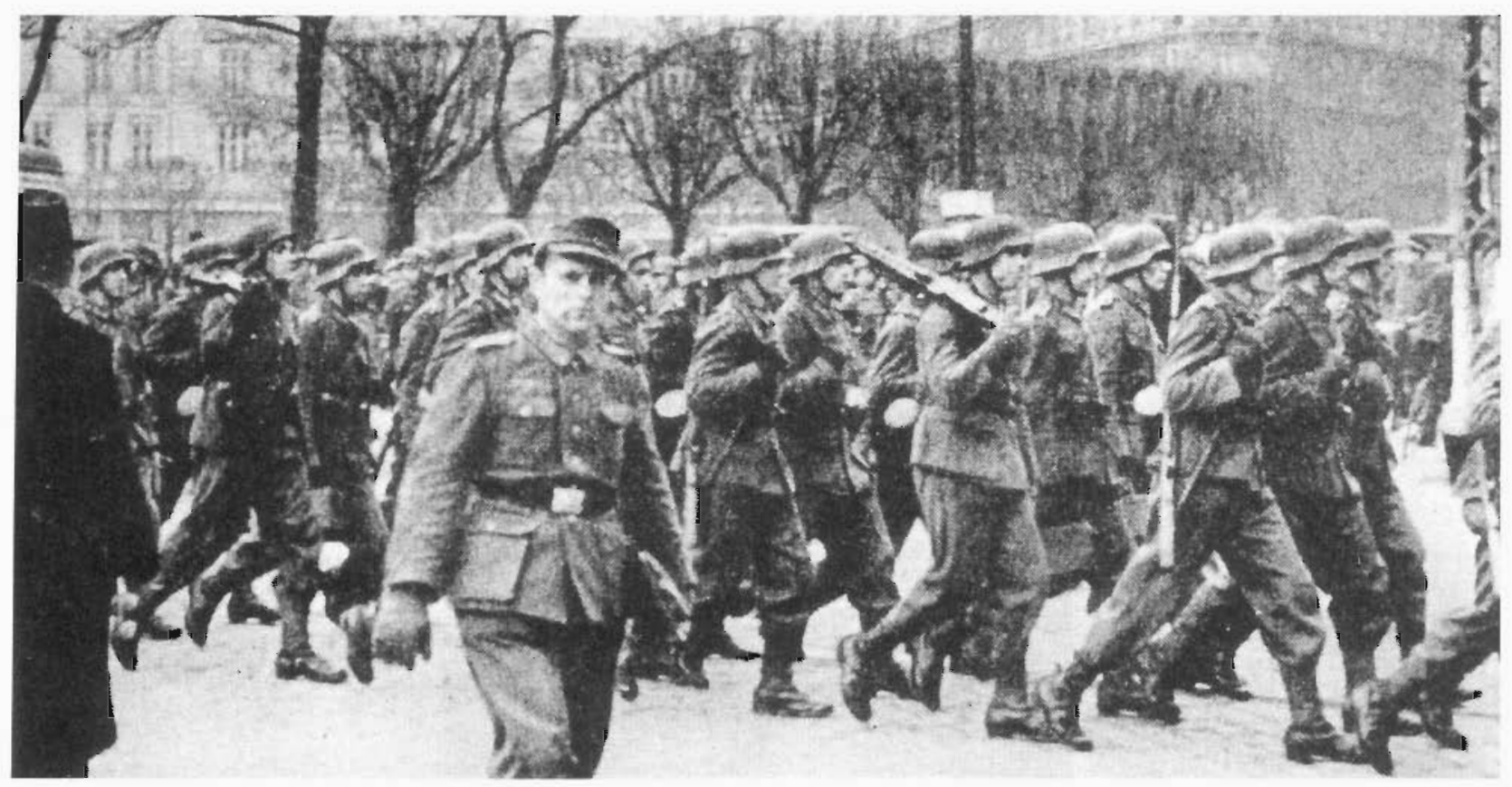

April 9, 1940 - German occupation troops in central Copenhagen.

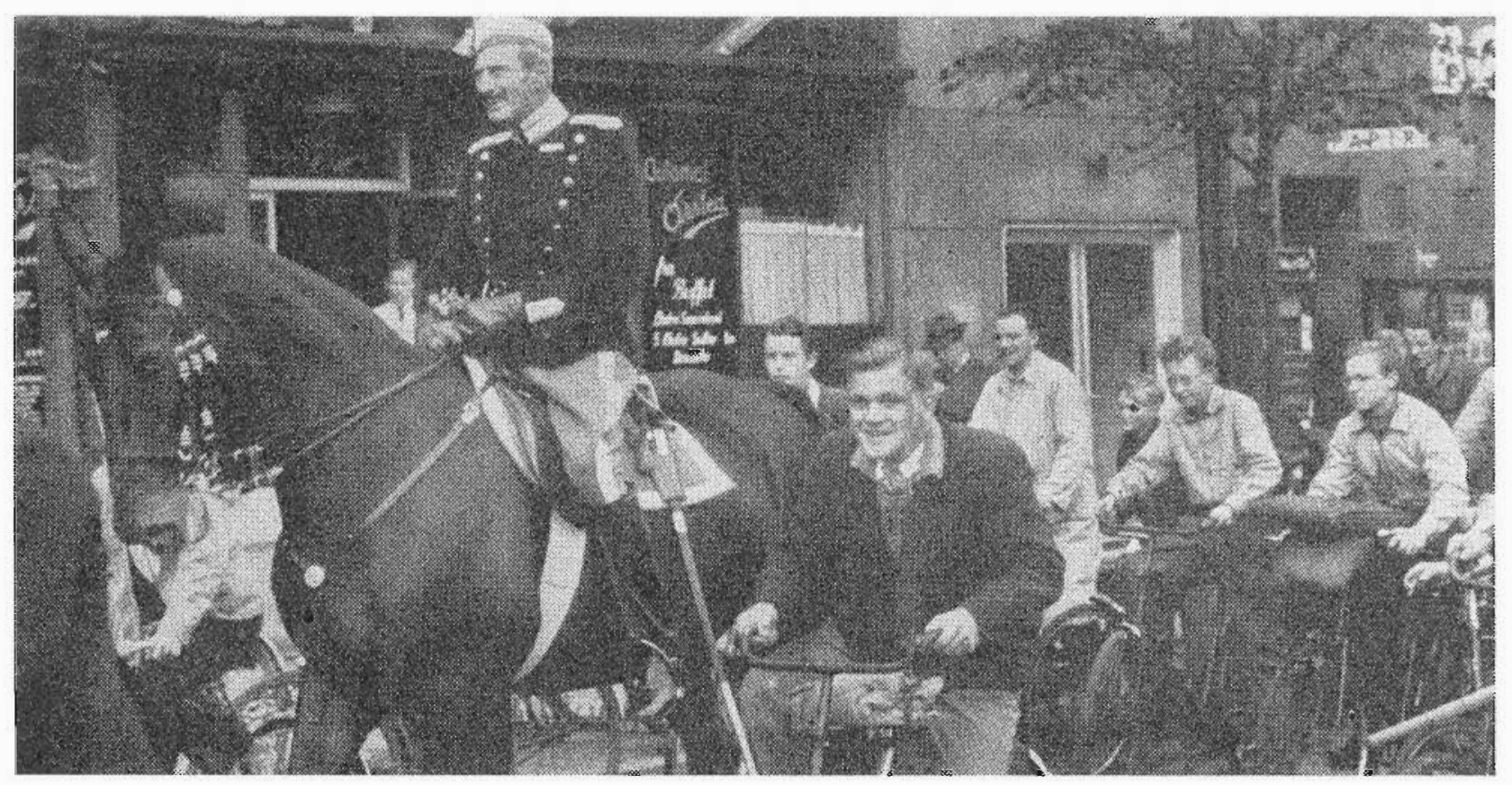

King Christian X on his daily ride through the streets of Copenhagen, guarded only by bicycle escort. 


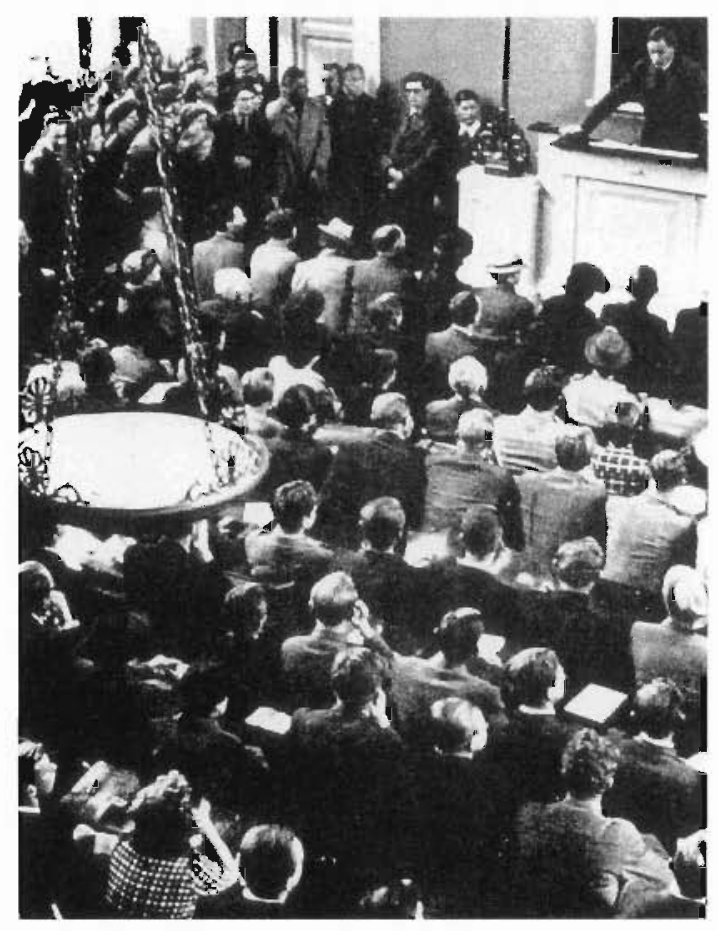

Students attending lectures by Professor Hal Koch, University of Copenhagen, on democratic principles, Christian ideals, and rights of minorities.

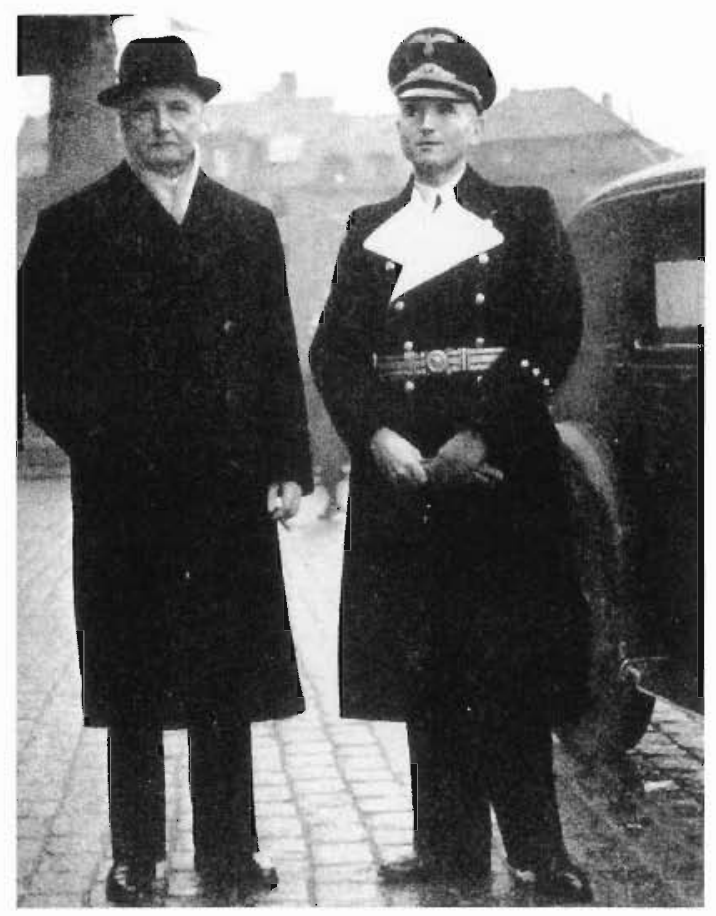

Werner Best (r.), SS-general and the German Reich's Plenipotentiary in Denmark, with Danish Prime Minister Erik Scavenius. 


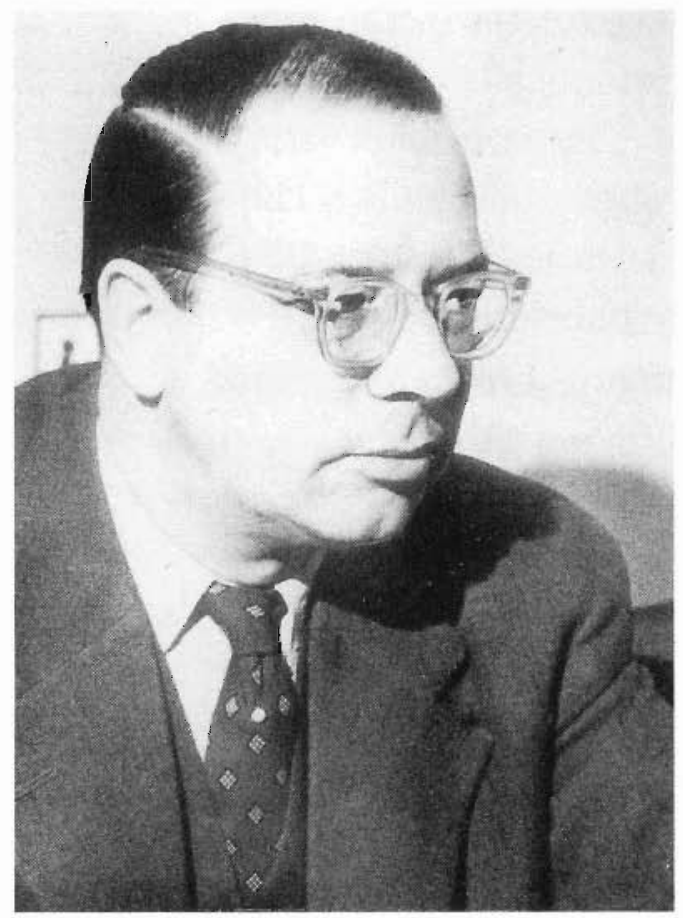

G.F. Duckwitz, official at the German embassy in Copenhagen, who in September 1943 courageously leaked the plans for deportation of the Jews. In the 1950s he returned as German ambassador to Denmark.

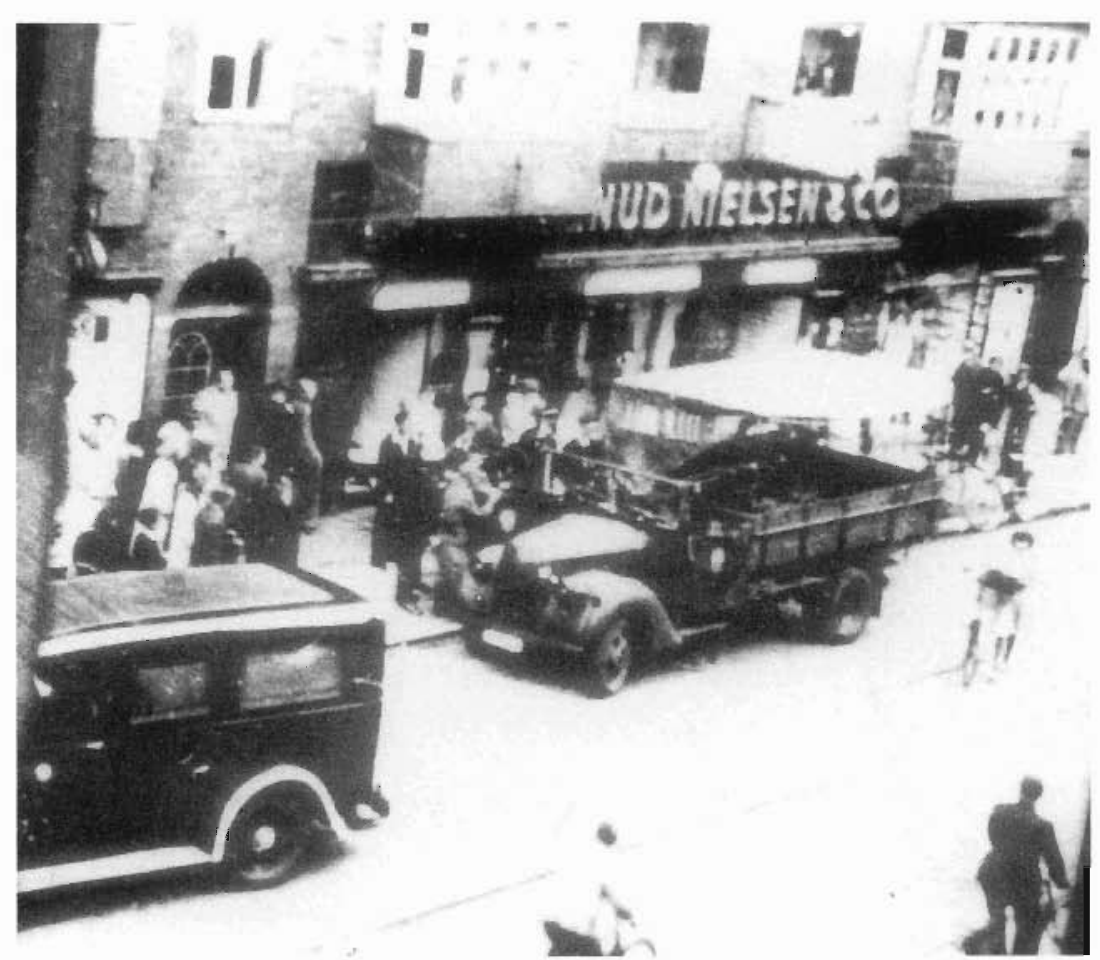

Two Danish Jews being arrested by Gestapo: a rare picture taken secretly by members of the Resistance. 


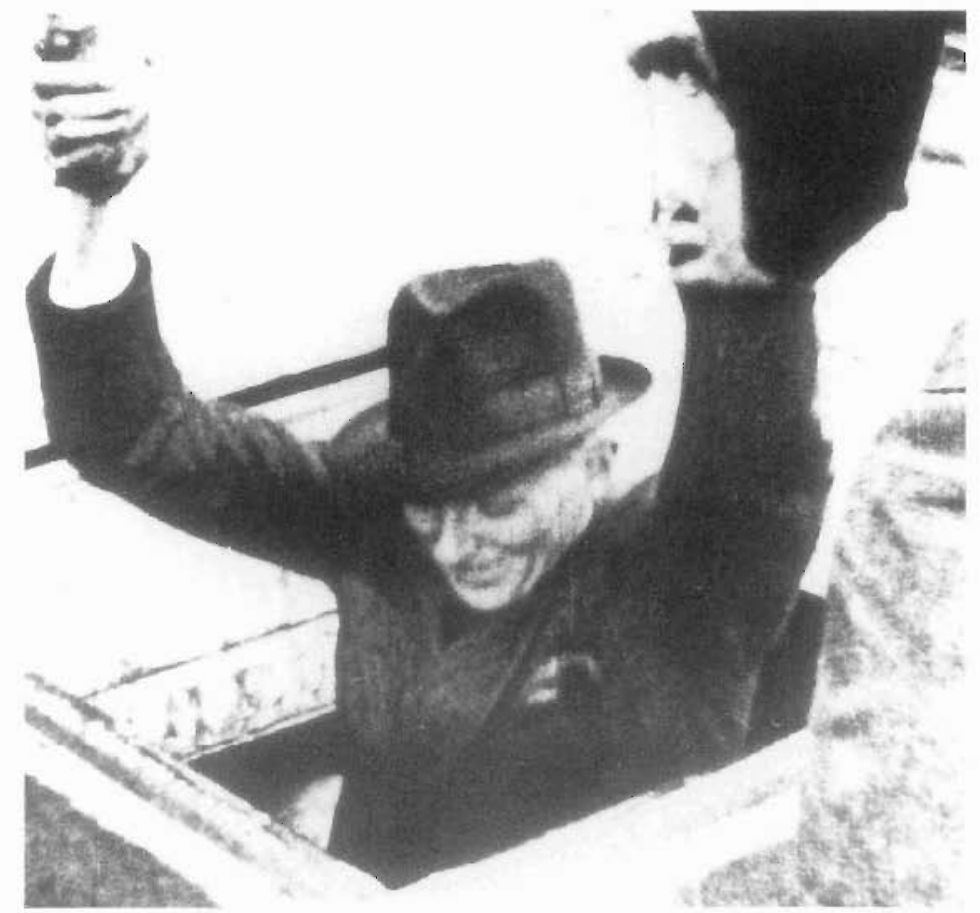

Jewish escapees had to be hidden under deck and often under a layer of ice.

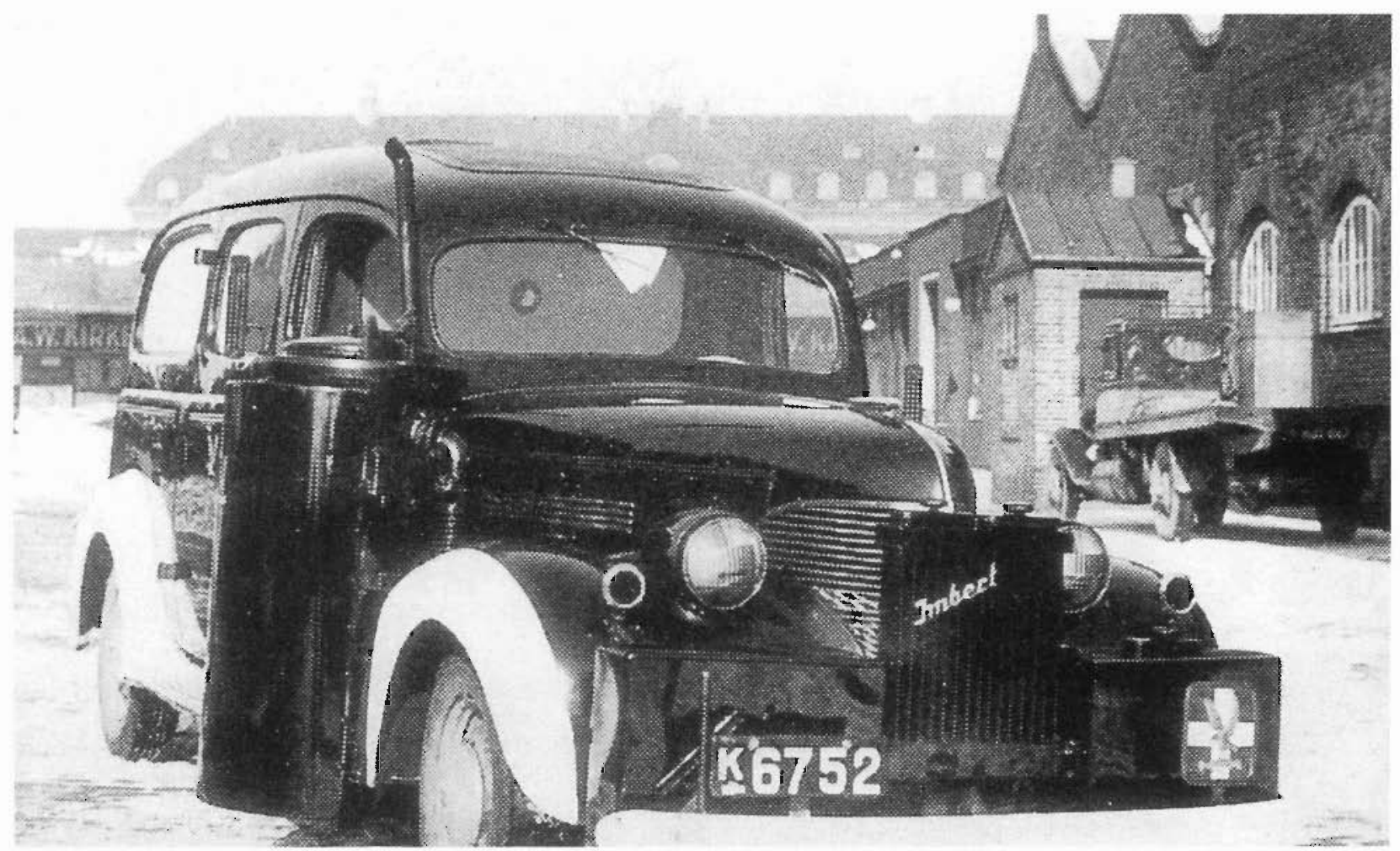

Ambulances served for undercover transportation of Danish Jews to escape boats. 


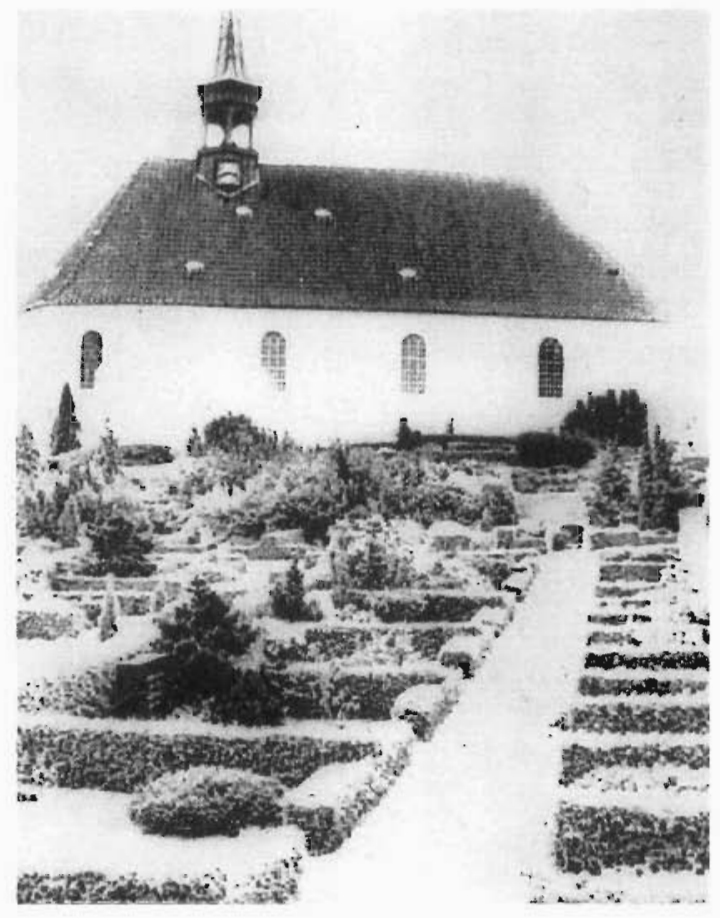

On October 5, the Gestapo arrested 80 Danish Jews in the loft of the Gilleleje Church in Northern Zealand. This was one of the worst tragedies during the rescue operations.

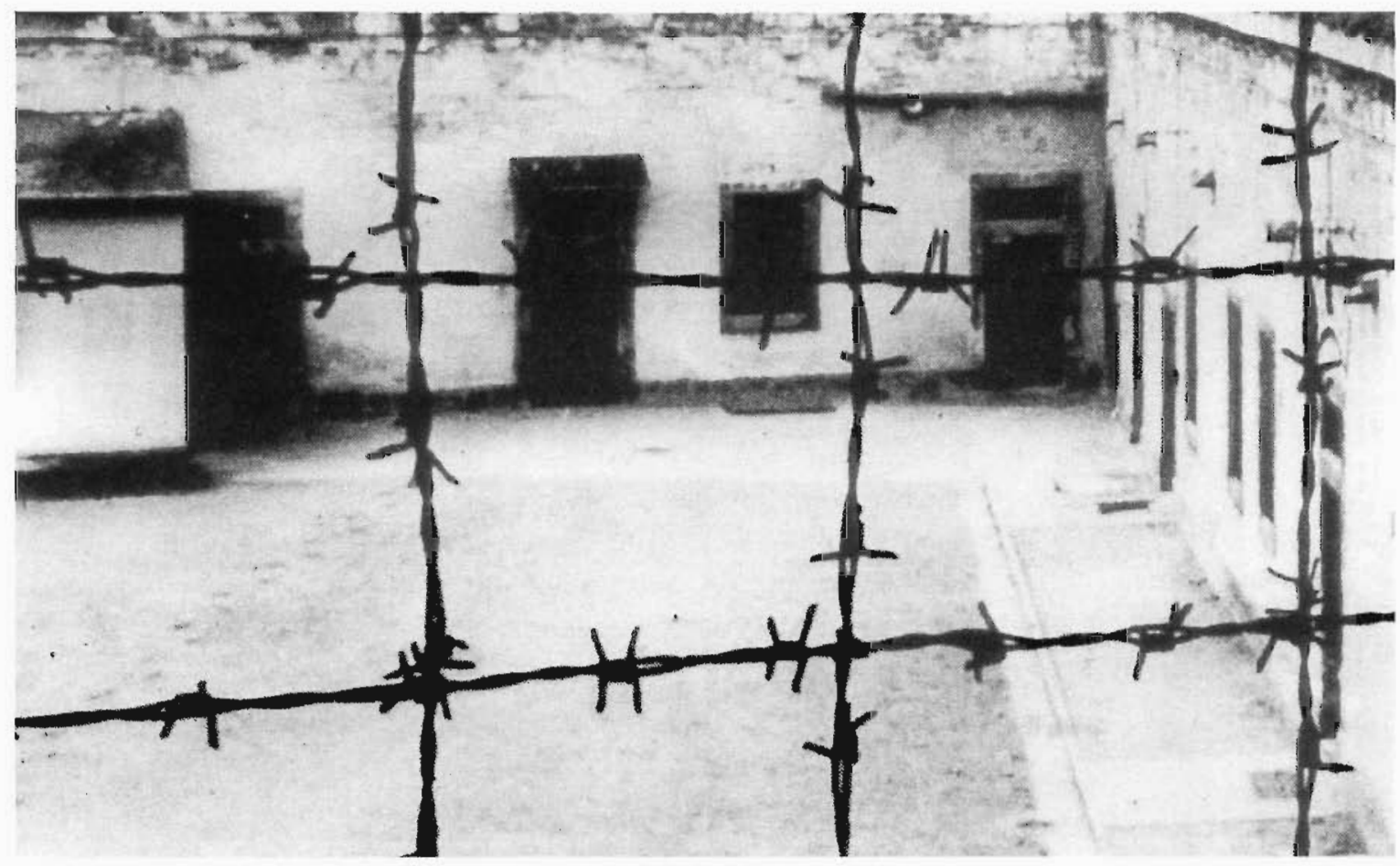

Theresienstadt Concentration Camp, north of Prague, where 481 Danish Jews were kept until the end of the war. Not one Danish Jew was sent to death camps, a unique arrangement demanded by the Danish authorities. 


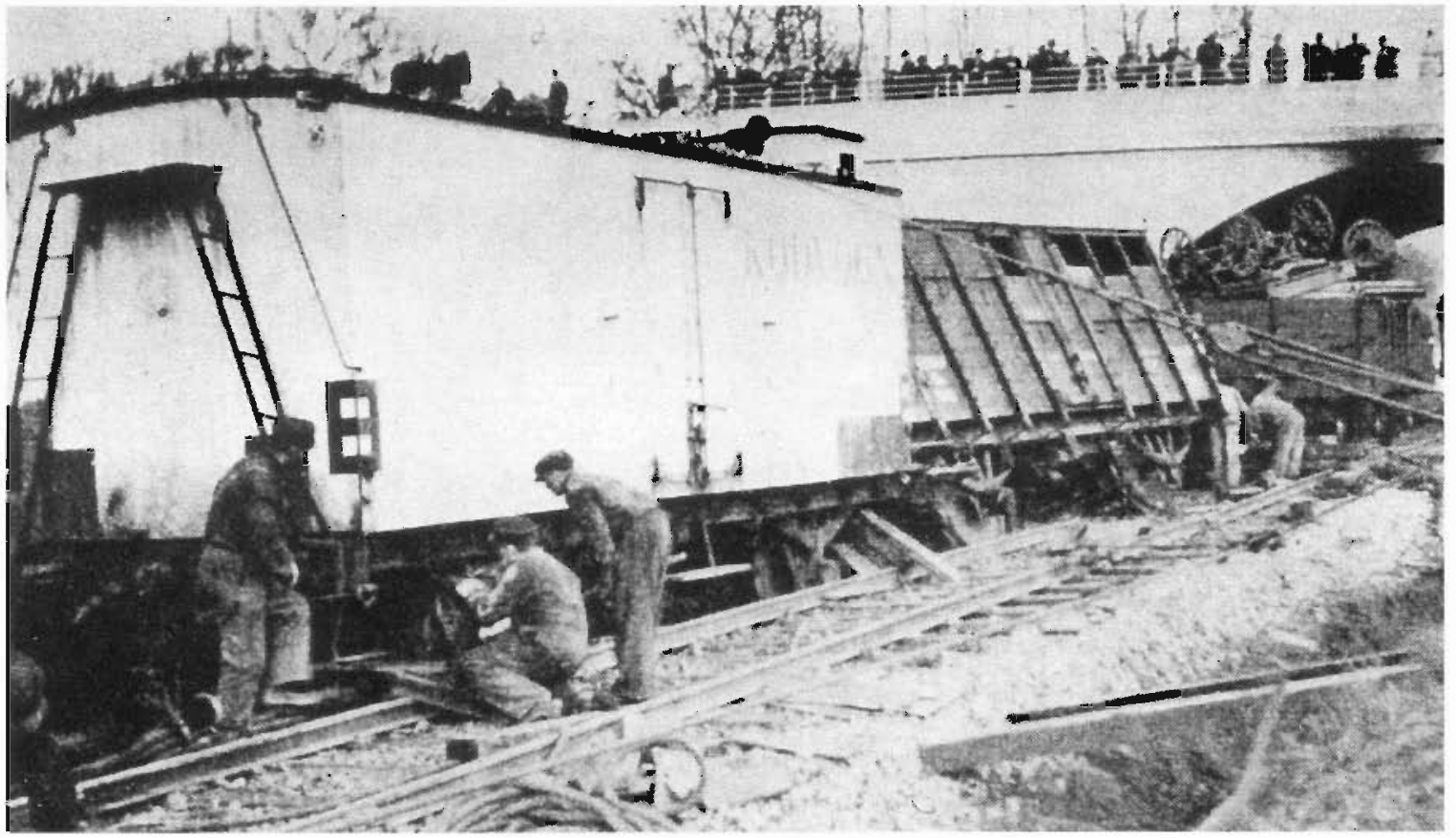

After Nazi action against the Jews, the Danish Resistance stepped up sabotage actions all over Denmark.

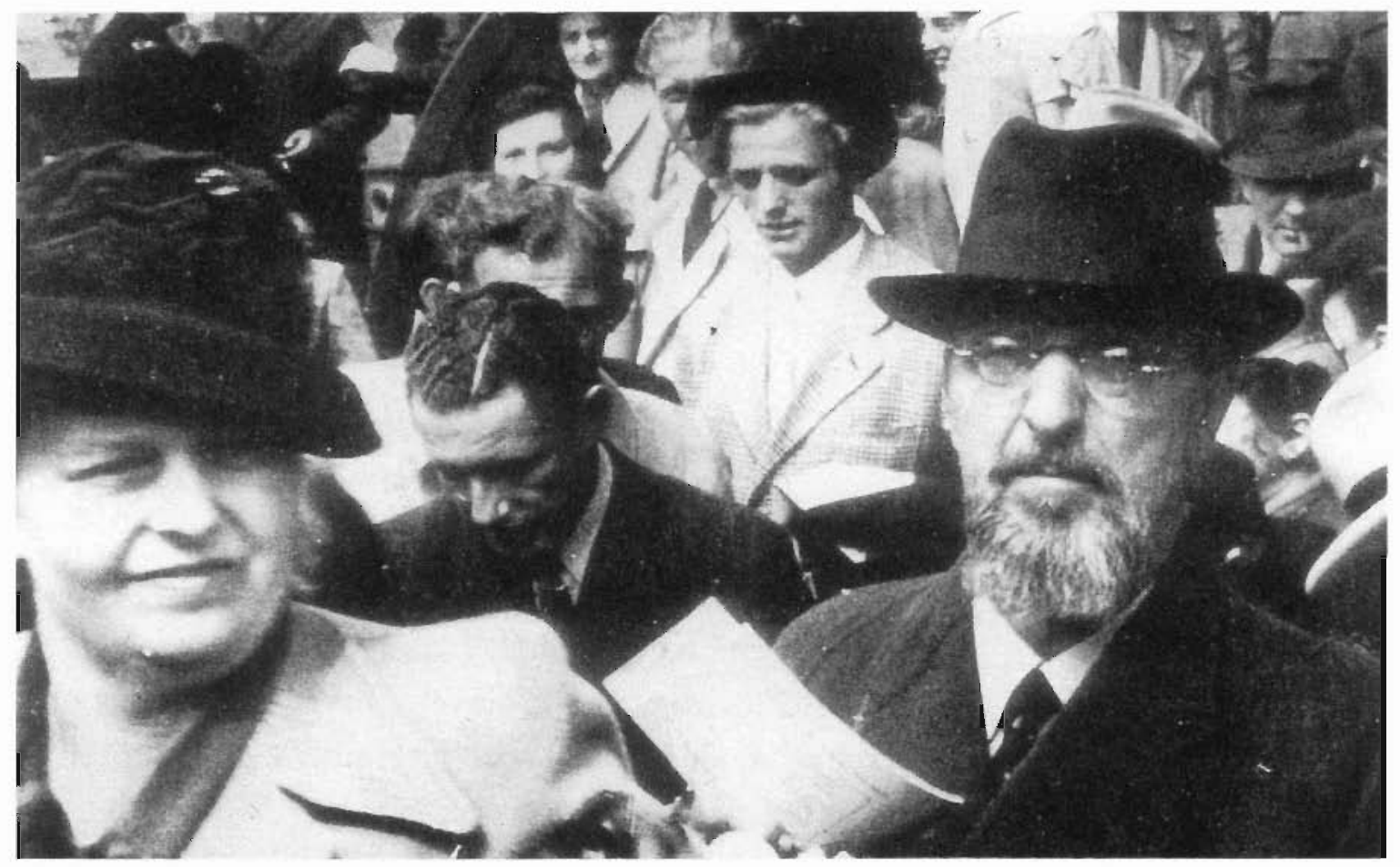

Chief Rabbi, Max Friediger rescued by the Swedish Red Cross, returns from Theresienstadt to Copenhagen on May 28, 1945. 


\title{
Rescue of Jews from Annihilation: Resistance and Responsibility in Nazi-Occupied Denmark
}

\author{
by Hans Möller
}

During World War II, Nazi Germany occupied Denmark. In October 1943, the Nazis staged a surprise raid on the Jews in Denmark in an effort to deport them to death camps. The entire Danish population reacted angrily and spontaneously and succeeded in rescuing almost all Danish Jews by helping them escape to neutral Sweden. This article, written in part as an eyewitness account, describes the events and attempts to explain the philosophy and political reality behind the unique reaction by the Danish people.

The text was given as a lecture with slides at the meeting of Friends of the Library, McGill University, on November 8, 1994.

Pendant la Deuxième Guerre mondiale, les Nazis occupent le Danemark et en octobre 1943, ils effectuent une rafle surprise contre les Juifs du Danemark en vue de les déporter vers les camps de la mort. La population danoise dans toute son intégralité réagit avec colère et spontanéité à cette rafle et parvient à sauver presque tous les Juifs danois en les aidant à s'enfuir en Suède, qui était neutre. Cet article, écrit par un témoin oculaire, décrit ce moment fort de l'histoire danoise et tente d'expliquer la philosophie et la réalité politique de cette réaction singulière du peuple danois.

Ce texte est celui d'une conférence accompagnée de diapositives prononcée dans le cadre du programme des Amis de la bibliothèque de l'Université McGill, le 8 novembre 1994.

ILLUSTRATIONS, pages 91-96.

\section{DEDICATION}

This article is dedicated to the memory of Leo Israel who passed away in Montreal, October 7th, 1995. As a young Danish Jew born in Copenhagen, Leo actively participated in the rescue until he himself had to be rescued and delivered into neutral Sweden. Later, he served bravely in the British Army helping to liberate Europe from Nazi occupation.

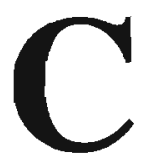
openhagen, Denmark, October 1st, 1943. German police raided homes suspected of housing Jews. Similar raids occurred all over Denmark which since April 1940 had been occupied by Germany.

This frightening event shook the entire Danish population into a near unanimous effort to rescue the Danish Jewry. A tiny nation in the grip of an all-powerful conqueror rose in fury against the occupation forces. Two Nordic peoples-conquered Denmark and neutral Sweden-turned to rapid and effective action against the Nazis.
The events became a legend even as they occurred. I hope by this presentation to convey the reality of the happenings by summarizing the main facts, by describing a few of the episodes and the reaction and feelings held by people involved, and finally, by attempting to explain how it happened as it did and what the reasons behind it all may have been.

I am doing this partly on the basis of personal experience. I was a 25 year old student then at Copenhagen University. Some of my family were inter-married with Jews. 


\section{Rescue of Jews from Annihilation}

\section{APRIL 9, 1940}

A surprise occupation of Denmark by German troops one early morning in April, 1940 began the chain of events that so shocked the Danes and deeply affected the future of their country.

To understand the events of 1943 we need to look back to the preceding years, and find out how Jews in Denmark responded to the tragic events from that fata] day and the special dangers they as Jews faced during that time.

After centuries of sovereignty and independence Denmark found herself occupied in a flash during the early morning hours of April 9th. Jews in Denmark saw this event as a Danish catastrophe and not just a Jewish one. Many are the sincere testimonies by rabbis and the leaders of the Danish-Jewish community expressing shock and horror at what happened to Denmark, "our quiet and happy fatherland and what about the King?" (Dr. Marcus Melchior). The eminent lawyer and jurist, Carl Bertel Henriques, said on that morning: "they have taken our beautiful country." A feeling of despair and uncertainty seized all Danish people. The Jews in Denmark felt themselves to be Danish, and Denmark considered them Danish citizens; they made no distinction.

How many Jews lived in Denmark in 1940? The statistics show 6450 Jews plus Jews in mixed marriages. Most of these belonged to old families, who had been in Denmark for very long, together with immigrants from Russia who came after 1903 and some 1500 Jewish refugees from Germany, Austria and Czechoslovakia. Some 2200 of these were actually not Danish citizens.

Two well defined groups of Jews had recently come to Denmark: 350 agricultural students (HECHALUZ) and 270 Jewish children (ALJAH) from Austria and Germany on their way through Denmark to Palestine on British visas. They were unhappily stuck in Denmark.

The Danish government made no distinction between the 6000 plus established Jews in Denmark, mostly settled in Copenhagen, and the young Zionist oriented recent arrivals. Officially, the Danish government firmly maintained that "Danish Jews" were the same as "Jews in Denmark."

The Germans from the beginning maintained that the occupation of Denmark was entirely and solely a protective measure and that they never had any intention of touching "the Kingdom's territorial or political independence."

The Danish minister of external affairs, Peter Munch, stressed this in his official note of protest over the occupation and held to that concept in subsequent negotiations with the German occupation forces. Nobody had any illusions as to the power relationship resulting from an occupation. Yet for a long time the Danish government insisted that the German officials in Denmark could not interfere with internal Danish matters. Thus, the fate of Danish Jews was intimately tied to the fate of all other Danish citizens and to the success of the Danish government in refusing German demands that would interfere with the Danish political and democratic system.

In the long run, however, could the Danish government maintain that the status of Jews in Denmark was an internal Danish matter not open to negotiations? Jews in Denmark had no other choice than to rely on the Danish government for their protection and do nothing to weaken the position of the government in its negotiations. While Jews were nervous and anxious, there was no panic. The minutes of meetings in the Congress of Jews in Denmark say nothing about the events; there was calm and life went on as before. C.B. Henriques had a deep rooted confidence in the Danish system of justice and believed that the government had the will and ability to shield the Jewish community in Denmark. "Keep calm" he advised all members of the Jewish community. Even among the Zionists in Denmark, especially the farm students (HECHALUZ), was this directive respected. After all, Denmark was their fatherland and the old Jewish families who since 1814 had enjoyed total equality with all other Danes had no desire to leave their country.

Incidentally, during the beginning of the German occupation the whole Danish population supported the government's policy and the demand for political independence. The Germans however soon began to 
make their demands. They objected for instance to the Jewish committees designed to assist Jewish refugees. As a result Jewish association activities were obliged to disguise themselves as study groups behind closed doors. This was in fact a condition common to most Danish associations in the country during 1940-41.

The Danish government insisted upon three conditions for "cooperation" with the Germans:

- no discrimination against the Jews

- maintenance of neutrality towards the nazi-fascist axis: Germany-Italy-Japan

- refusal to send a regular Danish army to fight on the eastern front

The German political and military administration, initially headed by non-Nazis with little interest in Nazification of free Danish institutions, agreed to these conditions, which were also accepted in the Foreign Office in Berlin.

\section{THE FIRST THREE YEARS OF OCCUPATION}

As the war intensified German pressure mounted. Heinrich Himmler, the Chief of the Gestapo visited Copenhagen in April 1941 and met with the Danish chief of police Thune Jacobsen. Himmler insisted that there was "a Jewish problem in Denmark" to which Thune Jacobsen replied that the entire Danist population agreed that there "is no Jewish problem in Denmark." For the next year this became the firm and consistent position beld by all Daaish officials. The Germans noticed this and discussed this situation in contemporary Nazi journals deploring the fact that the subject of Danish Jews could not even be discussed and that it was considered un-Danish to raise such a non-issue. As far as the Danes were concerned you could not discuss something that did not exist in Danish democratic thinking. All political parties in Denmark agreed to this policy.

Even the German ambassador to Dentrark, Cecil von Renthe-Fink, kept the subject of Jews in Denmark out of every report going to Berlin. This was clearly due to a desire on the part of the Germans to maintain a so-called "normal Danish-German relationship," which at that time was in their own interest. Germany depended to a large extent upon Denmark for food supplies.

In June 1941 an alarming event occurred. The Danish government gave in to German pressure to arrest and intern Danish Communists. This was indeed a blow to the Danish policy of protecting Danish citizen. The communists were not deported but interned in a camp in Denonark (Horserod). They were in fact sacrificed on the altar of negotiation. Danish Jews were shocked as they realized that the Danish Government was losing ground.

In November 1941 another alarming event occurred. The government signed the Anticomintern (Anti-Communist) Pact. The minister of External Affairs, Eric Scavenius, went to Berlin for the signing during which he met the Nazi leaders von Ribbentrop, Göring and Hitler. During this encounter they brought up the "problem of Jews in Denmark." When he returned to Copenhagen and reported, the Danish government and all political parties agreed that any talk of special legislation for Jews in Denmark was unthinkable and completely unacceptable.

An anti-senitic hate newspaper cropped up in Copenhagen and there was an attempt at burning down the Synagogue. The guilty person was tried by Danish court and given a very stiff sentence and the two publishers of the anti-semitic newspaper were jailed and fined. After an appeal to the Supreme Court the sentence was even sharpened. Anxiety among the Jews was calmed down for now.

Political leaders of the powerful Social Democratic party and the Federation of Labour Unions declared repeatedly that the Danish Government would fall if the Germans pressed for a "solution of the Jewish problem. " Lutheran church leaders agreed. The entire Danish population was united on this issue.

Some argued though that a Danish legislation for the Danish Jews might be easier to control than German interference, but government leaders passionately rejected any such legislation as being totally opposed to the Danish concept of citizens' rights and personal freedom. The protection of Jews in Denmark was firmly anchored in the Danish constitution and Darish democracy. 
Adolf Hitler was frustrated by the Danish manuer of evading collaboration with Nazi occupation forces. Like all Nazi officials he was taken aback by the cool Danish form of limited cooperation and angry at the German military lack of response to Nazi (Gestapo) imperatives. So he replaced his military staff in Denmark with an SS Officer, Dr. Werner Best, who became Plenipotentiary of occupied Denmark, November 1942.

A severe political crisis evolved in NovemberDecember 1942. A new Danish government was formed under the leadership of Erik Scavenius, who was immediately called to Berlin. Again the Jewish issue was avoided in Berlin, indeed it was not even discussed, and Scavenius agreed in Copenhagen to stand firm on this issue under any circumstances.

\section{THE YEAR OF CATASTROPHE}

The Spring of 1943 was relatively calm. A parliamentary election demonstrated the relative independence of Denmark and the small Danish Nazi party (NDSAP) lost votes compared to their standing in the 1939 election. Against all expectations Dr. Best took a moderate line. Danish underground resistance was becoming a strong factor in the opposition to the Nazis, and sabotage became very effective. An underground, illegal press now reached almost everybody (all over the country) giving more accurate information about the war events in Stalingrad, Africa and the Pacific.

The summer of 1943 saw wide-spread general strikes and open clashes between Danish demonstrators and German soldiers. More Danes became frustrated by the cooperative posture of the Danish government. Danish Jews kept calm and clung to the belief that only this very posture and its continued success was a guarantee against the dreaded German action. Jewish support of the King of Denmark, Christian X symbolized this belief and their trust in the government.

On August 28, 1943 the govemment was faced with an unacceptable ultimatum delivered by Foreign Minister von Ribbentrop. After a series of widespread popular demonstrations, the Germans introduced on August 29 emergency conditions and a curfew; they captured Danish military establishments, disarmed the armed forces, and took hostage a number of Danes including Jewish leaders such as chief rabbi Dr. M. Friediger, the supreme court attorney, C.B. Henriques and Axel Margolinsky. The deputy ministers now attempted to carry on a measure of Danish administration without political control.

For the Jews as for all Danes this was catastrophic, but especially of course for Jews. Many now considered fleeing to Sweden. On August 31 the offices of the Jewish Congress in Copenhagen were raided and the deputy minister of external affairs, Nils Svenninges, protested to Dr. Best who was evasive and denied any knowledge of the raid. In his denial he reiterated that "the Jewish problem has so far not been touched at all." We were all concerned about the words "so far."

Even worse, on September 17, a German police car brought German soldiers to the offices of the Jewish congregation, arrested the librarian, Josef Fischer, and confiscated books and archives. Luckily the main registers had on September 8 been transferred to the National Archives. Again the Nazi authorities brushed the matter aside and described it as a minor, unimportant episode insisting that this was not a real raid.

We know now that on September 8 Best had in fact cabled Berlin and asked for action against Jews in Denmark. This released the disaster; 10 days later, September 18, Adolf Hitler gave order to action. Dr. Best set the date to the night between October 1 and 2 .

Details of events from September 18 to October 1 are confusing and messages flew back and forth within the complex German bureaucracy. Later, everybody denied responsibility, but Dr. Best's cable was no doubt the action that released the horror.

Werner Best, who instigated the deportation of the Jews, played a curious double game, taking steps to block the execution of the order despite the fact that he himself had suggested it to SS Reichsführer Himmler. Double play and double dealing are, I believe, a common characteristic of Nazism. Dr. Best had long been an active Nazi before coming to Denmark. He demanded an SS police battalion to carry it out, but it is now believed that it was meant to further his own career and obtain a source of power against the German 


\section{Rescue of Jews from Annihilation}

army, which opposed him under the leadership of Hermann von Hanneken, Commander-in-Chief of the German Armed Forces in Copenhagen.

Curiously, Best himself told Georg F. Duckwitz, a German shipping agent in the German Embassy in Copenhagen, about the impending plans to arrest the Jews. Duckwitz tried to dissuade Best and even flew to Berlin to try to stop the telegram from reaching Hitler, and later to Sweden to investigate Swedisb intervention. When Best told him that raids would be executed Oct. 1-2, Duckwitz informed the leaders of the Danish Social Democratic party whom he knew personally. Duckwitz spoke Danish and had intimate knowledge of Denmark from before the war. He took a great personal risk in his actions.

One more episode is of considerable interest. Helmuth von Moltke, one of the most prominent leaders of the German resistance movement against Hitler, heard of the action planned in the German High Command of the Armed Forces when he worked in the department of international law and relations with foreign countries. He rushed to Copenhagen where he arrived on October 1st and talked to both Best and von Hanneken and warned them of the consequences of action against the Jews. He had personal contacts in Denmark. The warning came too late. Duckwitz's warning was decisive, not Moltke's. [I might just add that Moltke was jailed in 1944 and hanged on January 23, 1945, after the aborted coup against Hitler in July 1944. $]^{1}$

Rumours flew in Copenhagen but the Jewish leaders gave no warning, relying as always on the protection of the Danish government. The Bishop of Copenhagen as well as the Director-General of Danish Foreign Affairs, Nils Svenningsen, had both gone to Best, who "declared that persecution of the Jews in Denmark would take place only over my dead body." They related this to the Chairman of the Jewish Community C.B. Henriques.

So in fact, the Jews knew nothing and the Danish administration knew nothing. When the Social Democratic leaders, Hans Hedtoft and H.C. Hansen, visited $\mathrm{Mr}$. Henriques in his home late at night during curfew and said what Duckwitz had told them, the Jewish leader spoke only two words: "You're lying. " It took a long time to convince Henriques of the truth. $\mathrm{He}$ repeated despairingly that he just could not understand how it could be true. This was September 28. Now the warning went out in all directions with the speed of lightning. This warning became the salvation for thousands of Jews and Georg Duckwitz will forever deserve credit for his quick and courageous action.

Now all hopes for protection from Danish authorities, political or administrative, were crushed. The only solution now was illegal action and the Danish general population swung into immediate action by urging every Jew to go underground and wait for illegal transportation over the water to Sweden. The Swedish ambassador, von Dardell, had on October 3 informed Henriques that Sweden was ready to receive all Jewish refugees. The Danish Police was ready to assist and help dodge the German coast patrols.

On September 29, Rabbi Melchior publicly warned the Jews at the moraing service before the eve of the Jewish New Year to hide and flee. There would be no service held this New Year.

Warnings were systematically spread by the Social Democrats, priests, politicians, journalists, members of countless Danish associations, university students, doctors, lawyers and business people.

The King, Christian X, formally protested to Best, unaware that Best had instigated it. The underground Freedom Council appealed to all Danes to help directly. The Bishop of Copenhagen, Hans Fuglsang-Damgaard sent out a denunciation of the Lutheran Church of Denmark which was read from every pulpit across the land: "The persecution of Jews conflicts with the humanitarian concept of neighborly love and the message which Christ's Church set out to preach. We shall fight to preserve for our Jewish brothers and sisters the same freedom which we ourselves value more than life."

The raid was carried out while the state of emergency was still in effect during the night between October 1 and 2 by Gestapo troops, who apparently were instructed not to force the door if there was no response to the doorbell. 202 Jews were caught that night in Copenhagen including 30 people in a Jewish old people's home next to the synagogue who received 


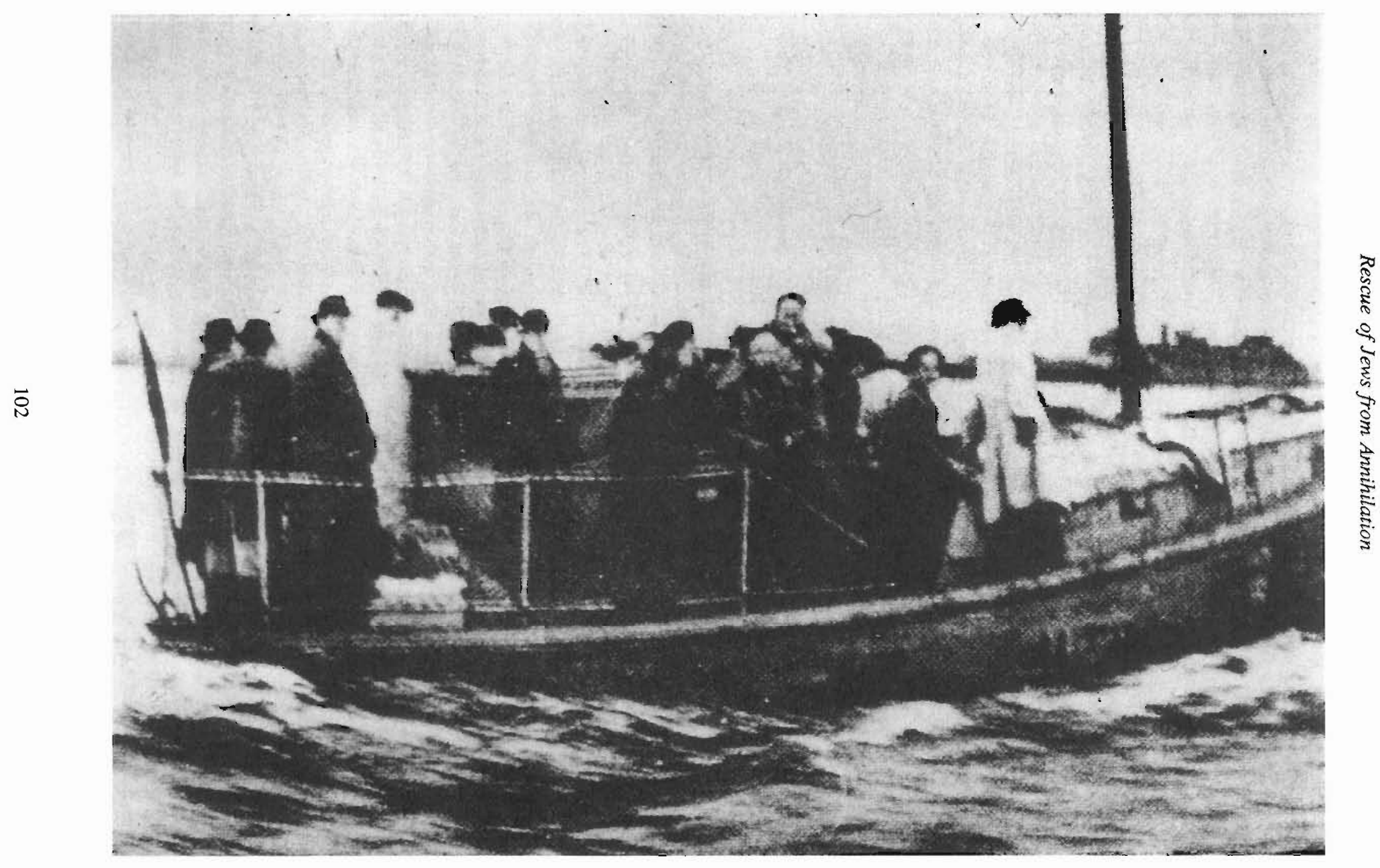

Figure 1. When approaching the coast of Sweden, Jewish refugees could come on deck of the fishing boat to sight the "land of freedom." 
especially brutal treatment. The Danes were not aware of the existence of this. From the Nazi point of view, the operation was a fiasco. Ultimately, 481 were seized and transported to Theresienstadt in Bohernia (Czechoslovakia), a transportation camp rather than a death camp. 51 Danish Jews, mostly elderly persons, died en route to this camp or after arrival.

\section{RESCUE AND FLIGHT}

What happened to the Jews that escaped capture that fateful night? Miraculously, we managed to hide over 6000 Jews mostly in Copenhagen and the surrounding area. Then started the difficult and dangerous task of organizing transports to Sweden during the cold and damp October nights. Rescue rings were based on existing organizations. There were teachers' rings, priests' rings, journalists' rings, doctors' rings and of course the underground resistance organizations. All diverted spontaneously and quickly their functions to total mobilization for flight. Hospital staffs held conferences daily to delegate duties for conveying Jews to the fishing boats waiting at the coast and transporting them in ambulances. Students closed down Copenhagen University and schools to help retrieve Jews bidden in the countryside. Buses, taxis and bicycles were used for transport. There was much unorganized collective helpfulness: cooperation of anonymous strangers in giving keys to Jews, boarding them in boats without payments etc. This was a collective social movement, simultaneously, spontaneous and without structures, both tolerated and supported by Danish officials at different levels.

There was much haste, much improvisation, much imagination, daring and courage. Fishermen were enlisted for the perilous trips. Money had to be raised every day to pay them reasonably for their risk. Only rarely did people take advantage of the situation. A few scoundrels did but never at the risk of the lives of the refugees. Nobody was ever left behind because of lack of funds. It was more typical to encounter touching willingness and courage by very ordinary people who did not personally know Jews.

There was an army of helpers, couriers, chauffeurs and guides. The actual coordinating of arrangements for sailing and for biding the Jews was done by several groups near the departure sites at Lynby, Humlebaek, Helsingor. There were neighbours united by mutual interest and trust. Tens of thousands of Danes were involved. It is estimated that every Jew had 10-25 contacts with Danes helping so that at the very least 70,000 persons were involved. A united population stood behind the action.

Sadly, 190 Jews were arrested during the risky efforts to escape but 7,750 made it to Sweden of whom 686 had fled because of Jewish spouses (Fig. 1).

I am often asked what it was like be involved in this rescue effort. Well, it was datngerous and the Germans were vigilant enough and ever present. It gave you a chill in the spine and a sensation in the stomach when you saw the Germans or feared that they would turn up around the next corner and question you or that they were watching you from a hide-out.

Yet, the urgency drove you, the terrible responsibility for human lives, the need to be calm and to calm the people who felt hunted like dogs. There was no question about doing it; it would have been harder to decide not to participate. It was indeed a duty to do it and one did not expect to be thanked for it. It took 4 to 6 weeks, and it seemed long; it was exhausting because the days were needed to organize and the nights for action. There were long hours of waiting in hiding in woods in the dark and cold nights. When the moment came you struck fast or aborted the action if it seemed unsafe.

There are no archives left to record these actions, no reports, no shipping registers, no letters, no diaries, no receipts for payments! Of course not. All was done verbally. All we have is individual reports made later from rescue workers and refugees. There are in fact 120 such reports. Some are printed up in book form.

They read like detective novels; they may not be as well structured as novels, but the thrill and chill is real and tatally true.

Many are the anecdotes, sad, scary and at times, yes even funny. What is typical is bow much imagination and cunning is needed, not only strength and courage. Many a time all seemed lost-unless one could act very fast and very calmly. 


\section{Rescue of Jews from Annihilation}

What happened after October/November 1943? The experience of acting outside the law in liberating the Jews also liberated the Danes from their previous deeprooted respect of authority and fear of provoking reprisals. Sabotage and other resistance actions mounted rapidly. The resistance movement became very powerful. The Germans responded with anonymous assassinations and executions of saboteurs.

The Nazis stood astounded and to some extent helpless before the strange phenomenon of the rescue operation. They did not grasp the profound motives which led the Danish people to its energetic deed, nor did they, I think, understand the way it was carried out. How could this calm, friendly, easygoing nation have changed overnight? They could not comprehend what was clear to every Dane, from the simplest to the most brilliant intellectual. It was now time to act. The majority of men and women now sided with the resistance movement. The Nazis themselves gave the signal! They tried to put the actions and behaviour of the Danes in a ridiculous light: "This ridiculous little country" as Dr. Best called it.

The Danes had a real talent for exploiting the psychological weaknesses of the Nazis, such as their blind faith in a piece of official looking paper, their respect for authority, their certain haughtiness. I think many Germans never fully understood the Danes, who did not mind playing the fools vis-à-vis haughty Nazis. Danes learned to play on the need of even the Gestapo agents to appear as decent people in Danish eyes. As a result the "stupid" Danes carried out a most dangerous and daring operation and got away with it. They demonstrated a strange audacity and toughness, surprising for the Danes who more often appear smiling, mild-mannered and even meek. The audacity seemed to spring from coolness and realistic imagination guided by alert observation - these were the hallmarks of Danish underground fighters. It first became clear in October 1943 that these were the preserves of many Danes among all sections of the population. The professor and the fisherman, the doctor and the taxi driver, the priest and the policeman-all understood each other without as much as saying a word.

There were many difficulties to overcome and not just the Gestapo police and patrol boats-there was the weather, there was the mechanical breakdown of motors in the boats, there were difficulties in organization and communication. What made it work on the whole, with relatively few arrests, was a united people from whose ranks rose leaders unknown a day or two before, a people determined to prevent the Nazis from carrying out their evil plans, a whole nation-volunteers in body, soul and mind. Difficulties were overcome and a mass rescue operation succeeded.

There were tragic accidents; some boats capsized. On the night of October 5-6 two boats sank, one with nine aboard. Some committed suicide, some even after safe arrival in Sweden, such as a celebrated Danish author, Henri Nathansen. The flight caused great anxiety and fright among the Jews; the rescuers often had to spend time, imagination and cunning in helping to calm down the emotions. Sedatives were needed, especially for small children.

\section{NATIONAL UNITY AND MORAL RESPONSIBLITY}

What were the results and how was it that Danes acted as they did?

The state of emergency declared by the occupation forces August 19, 1943 provoked the Danish resistance and annulled Danish self-government. The defense of the Jews was governed by a total consensus among both Danish authorities and the Freedom Council.

There was not the slightest disagreement with the view that the rights and the lives of the Jews had to be protected.

It was not just a question of altruism or benevolent paternalism toward a minority but rather one of selfdefense. What is significant here is that for Danes national consciousness and democratic consciousness are one and the same. The struggle for national existence included the struggle for equal rights of the Jewish people.

I was, as many other university students at the time, deeply moved and influenced by a series of public lectures given in 1940 by a young theologian at the University of Copenhagen, Hal Koch. He wanted to renew the belief in the democratic principles underlying Danish society and political life. Later in January 1942, 
Hal Koch tied these principles to the defense of Jewish people. He said, for instance, that "the country's fate will be decided by our ability to maintain truth, justice and freedom and pay the price."

The Danish conscience was a product of the positive obligations of Christians towards Jews. The Danish National Lutheran Church had long formally denounced anti-Semitism. The attitude of the King was symbolic, and immortalized by the legend that he donned or threatened to wear the yellow star. The fact that Denmark is blessed with a harmonious, homogeneous society and has been for centuries is yet another factor but not in itself a satisfactory explanation.

It may be well worth looking deeper into this consensus of views and the particular form of democracy found in Denmark. Without going into an elaborate review of Danish political history I would prefer here to relate for you a chapter of Danish literature which I believe is at the root of all this.

The 19th century Danish literature is incredibly rich and flourishing. It gave us Danes wonderful and original prose and poetry, it gave the world such famous writers as Hans Christian Andersen, Søren Kierkegaard and the literary critic George Brandes, who incidentally was Jewish.

First Andersen (1805-75), the world famous story teller and author of hundreds of fairy tales. His dual theme is the ultimate victory of good and the innocent over the evil and the calculating. His writing is true poetry combining tragedy, comedy and humour. His philosophy and values are simple but sincere. He maintained to the end of his life an unswerving faith in life's fundamental goodness, its wealth and beauty. He maintained that "every living being is privileged to live in his own way." He disliked people who would not recognize how many different kinds of values there are in life. Each man lives his own way. He had a profound respect for the rights of the individual and created as an artist a world of individuals, all so full of real life.

A contemporary of Andersen was Søren Kierkegaard (1813-55), internationally famous philosopher and religious thinker. His philosophy is in part hard to comprehend and still the object of lively debate. His writing style is brilliant even in translation. He is one of the very great writers of the western world. His thoughts exerted a great influence in Denmark and still do. He stressed in all his philosophy the value of individualism and the freedom of the individual to decide. As he said "the subjective is truth."

Yet another contemporary of these two renowned authors was Grundtvig (1783-1872). Nicolai Frederik Severin Grundtvig, perhaps less known to you, although some of you may have heard his name in connection with Danish folk high schools. He was a giant of a writer, religious leader and politician. He too stressed the rights of the individual including the right of all to have their own version of Lutheran belief within the church. One of his famous statements is "first man, then Christian. "Human life is a way to Christian life or as Grundtvig puts it "a living sinner is better than a dead saint."

What is interesting about Grundtvig as a politician is not his views on specific matters but his uncompromising struggle for intellectual freedom in all contexts, unlimited. To him freedom itself was more important than democracy. He fought what he called "the majesty of numbers." He feared the influence of powerful groups in debating the new democratic Constitution in Denmark (1849). He insisted that an opinion does not at all get better from the fact that the majority adheres to it. An encroachment on freedom is bad, no matter whether it is a majority, a minority or a tyrant who enforces it. The individual must be protected against the group and the majority.

I have briefly here described three giants in Danish literature, Andersen, Grundtvig and Kierkegaard.

Is there a relation between literature and politics or does literature reflect political and philosophical ideas? I believe the literature reflects and even develops values of life, the meaning of life and ideals, and that these make political action possible. My belief is that 19th century literature in Denmark laid the foundation for the political and social movements including the type of democratic government, the type of Welfare State you find in that country. I believe 19th century literature laid the theoretical cornerstones for the 20 th century evolution of public and personal life in Denmark. 
While Andersen and Kierkegaard focused on the rights and responsibilities of the private individual, Grundtvig carried this out into public life, whether in Church, Parliament or School. Grundtvig stressed the value of debate and emphasized the importance of the Opposition and public opinion. He always belonged to the Opposition. Grundtvig's views were radical-liberal and he demanded freedom in every civic field. He deeply influenced Danish political thought and legislation.

Today, Danish politics is coloured by the fact that there are many political parties represented in parliament, not just two or three. These parties flourish, change, and move up and down as a reflection of numerous and changing facets of public opinions. In contrast, in North America we are used to a system that only allows for very few and general opinions. Here a sharp viewpoint tends to shock or embarrass people. In Denmark, the rights of the individual go very deep in all public life. You see it reflected in every newspaper -and there are many newspapers in Denmark. You see it reflected in the manner in which the welfare program is administered. They tend to stress universality, but there is also generous allowance for individual differences and individual treatment.

I believe all this is the legacy of Andersen, Grundtvig and Kierkegaard. Probably Kierkegaard's influence on present day values in Denmark is mostly indirect but I cannot help thinking of him when I hear (and remember) Danes argue and question everything in sharp, provocative ways. Denmark is one of the countries in the world where dislike of regulations and prohibitions of any kind is most pronounced.

I believe all this formed the basis for attitudes to citizens' rights within the Danish democracy, concepts that came to the test during those fateful years in Denmark's history 1940-45 and that were polarized in the events of October 1943.

What happened then after the war? Denmark was liberated by British troops on May 5, 1945. Even before then, in fact in April of 1945, the Danish Jews were brought back from Theresienstadt thanks to the efforts of the Red Cross and the personal interventions by the famous Swede, Count Folke Bernadotte. The cortege of white buses going through Denmark en route to Sweden was a heartening sight for us all.
It is well worth noting that the Danish administration from October 1943 to April 1945 never left the Jews deported to Theresienstadt alone. There was not one week that they did not pressure the German authorities in Copenhagen and Berlin to let them return to Denmark, demand the right to visit and inspect the camp, request reports on the conditions of health, whereabouts etc. All received parcels from Denmark and none of the Danish Jews was transported out of Theresienstadt to a death camp. The Danish authorities continued to consider the fate of the deported Jews a Danish responsibility to the very end.

After May 5, 1945, the Danish Jews could return to Denmark and most did, although some stayed in Sweden, and some went overseas to the USA and Canada.

What finally happened to Dr. Werner Best? He was tried in Nüremberg and Copenhagen and condemned to death in 1948. Yet his sentence was commuted to jail. He was released from jail in 1951. In October 1985 it was reported that a Düsseldorf Court (in Germany) dropped all charges for war crimes due to his age (over 80). He died in 1989.

\section{Notes}

1. I am indebted to Professor Peter C. Hoffmann, McGill University, for information about Helmuth von Moltke.

Documentary material regarding underground resistance during the Nazi occupation of Denmark (1940-1945) is very sparse due to the very nature of such activities. This includes all actions related to the 1943 rescue of Danish Jews; documents such as lists of names, schedules for transport and other records were either not prepared in writing or routinely destroyed. Consequently, historians have largely relied on personal, eyewitness accounts, prepared after the liberation of Denmark in May 1945.

McGill Libraries has in its possession a collection of books and pictures as well as samples of illegal newspapers printed by resistance workers underground during the occupation. The literature is mostly in Danish and English. Further information may be obtained from Frihedsmuseet, Churchillparken, 1263 Copenhagen K, Denmark, the museum of the Danish Resistance. In collaboration with the Royal Danish Ministry of Foreign Affairs this museum prepared a 


\section{Rescue of Jews from Annihilation}

panel exhibition of pictures and texts titled October 1943: The Rescue of the Danish Jews from Annihilation (1993). A Danish historian, Therel Straede prepared the exhibition and wrote an accompanying booklet in English with the above title and in French with the title Octobre 1943: Le Sauvetage des Juifs Danois Menacés d'Extermination (Copenhague 1993).

\section{Bibliography}

Following is a list of selected titles on the occupation of Denmark and the Rescue of Danish Jewry:

a.Dlegal Danish Newspapers etc. 1943-1945

10 original illegal newspapers

1 booklet about resistance in Odense, aug. 1943

1 label warning against informers

1 air-dropped leaf of British origin

2 false illegal newspapers prepared by Gestapo

b. Publications $1945-1995$

Overgaard Nielsen, Poul. ... men aldrig kan et Folk forgaa. Copenhagen: Forlaget Anker, 1945. (...yet never shall a people perish (unless it wishes so itself))

Meyer, Torben L. Flugten over Øresund. Copenhagen : Jespersen og Pios Forlag, 1945 (the escape across Oresund)

Fra Undertrykkelse til Befrielse. 5 aars Besaettelse i Billeder. Copenhagen:Politiken, 1945 (From suppression to liberation, five years of occupation pictures)

Fabritius, Albert. La littérature clandestine du Danemark occupé. Publié a l'occasion de l'ouverture de la première session de 1'Unesco à Paris. Copenhague 1946

Bertelsen, Aage. Oktober 43. Copenhagen: Gyldendal, 1952

Haestrup, Jørgen. Panorama Denmark. From occupied to ally: Danish Resistance Movement $1940-45$. Copenhagen :Press and Information Department of the Royal Danish Ministry of Foreign Affairs, 1963

Naes-Hendriksen, Carl. Aarets storste Begivenheder $i$ Billeder. Det bedste fra "Den Danske Kamp" 1940-43. Fruens Bøge, Denmark: A/S Bogforlaget Dana, 1966
(Main events in pictures from the Danish Resistance 1940-43)

Naess-Hendriksen, Carl. Aarets storste Begivemnheder $i$ Billeder. "Den Danske Kamp" 1943-45. Fruens Bøge, Denmark: A/S Bogforlaget Dana, n.y. (Main events in pictures from the Danish Resistance 1943-45)

Yahil, Leni. The Rescue of Danish Jewry. Test of a Democracy. Philaldephia: the Jewish Publication Society of America, 1969.

Jacobsen, Frode. I Danmarks Frihesdsraad, 1-2. Copenhagen: Gyldendal, 1975 (Denmark's Freedom Council)

Haestrup, Jørgen. Secret Alliance. A study of the Danish Resistance Movement 1940-45, vol 1-3, Odense: Odense University Press, 1976.

Nissen, Henrik S. Scandinavia during the Second World War. Minneapolis: The University of Minnesota Press and Universitetsforlaget Oslo-Bergen-Tromsø, 1983.

Sørensen, Lars Peter. Distrikt 14. Om vaabenmodtagegrupperne i Distrikt Silkeborg og deres aktiviterer 1944-1945. Them: Dixit 1984. (Air-drops of weapons in the Silkeborg district 1944-1945).

Moller Jensen, Ole and Bendixen, Mogens. Den lange vej til glaeden. Herning-egnen under besaettelsen 19401945. Poul Kristensens Forlag, 1987 (The long road to joy, Herning district during the occupation 1940-1945)

Dansk Jødisk Historie 24. Udg. af Selskabet for dansk jødisk historie, Maj 1987 (History of Danish Jews)

Lowry, Lois. Number the Stars. Boston: Houghton Mifflin Company, 1989.

Sørensen, Lars Peter. Radiogrupperne Moses og Cain. Sejs: Forlaget Eureka, 1992 (The work of radiogroups in connection with weapon-drops during 1944-1945)

Bergh, Ole. Traefningen ved Hollandshus, Rold Skov august 18, 1943 (The shoot-out in Rold Forest, August $18,1943)$

Jensen, Poul Westergaard. Kaere Faetter. Striden om modstandsbevaegelsen $i$ jylland 1944-1945 (The controversy over the resistance movement in Jutland 1944-1945) Them: Dixit, 1990.

Oktober 1943: Jodisk Orientering, 64. aargand nr. (. Copenhagen, Oktober 1993. 
October 1943. The rescue of Danish Jews from Annihilation. Copenhague: Royal Danish Ministry of Foreign Affairs and the Museum of Danish Resistaance 1940-1945, 1993.

Octobre 1943. La sauvetage de juifs danois menacés d'extermination. Copenhague: Ministère Royale des Affaires etrangères du Danemark et Musée de la Resistance du Danemark 1940-1945, 1993.

Dethlefsen, Henrik. De illegale Sverigesruter 1943-1945. (lllegal routes to Sweden) Odense University Press, 1993.

Pundik, Herbert. Det kan ikke ske i Danmark. Jodernes flugt til Sverige $i$ 1943. Copenhagen: Munksgaard, 1994 (It could not happen in Denmark. The escape of the Jews to Sweden in 1943)

50-aaret for Oktober 43. Graested-Gilleleje Kommune, n.y. (50 year anniversary Ocktober 43, Municipality of Graested-Gilleleje)

Frandsen, Sten Bo. Dänemark der kleine Nachbar im Norden. Aspekte der deutsch-dänischen Beziehungen im 19 und 20. Jahrhundert. Darmstadt: Wissenschaftlich Buchgesellschaft, 1994.

Lilienheim, Henry. The Afternath. A survivor's odyssey through war-torn Europe. Montreal: DC Books, 1994.

Matas, Carol. Lisa. Toronto: Scholastic Canada Limited, 1994.

Matas, Carol. Jesper. Toronto: Scholastic Canada Limited, 1994.

Fogelman, Eva. Conscience and Courage. Rescuers of Jews during the Holocaust. New York: Doubleday, 1994, 205-207.

Kreth, Rasmus og Mogesen, Michael. Flugten til Sverige. Aktionen mod de danske joder oktober 1943. Copenhagen: Gyldendal, 1995. 